\title{
Spinal curvature of cultured Japanese mackerel Scomber japonicus associated with a brain myxosporean, Myxobolus acanthogobii
}

\author{
Hiroshi Yokoyama ${ }^{1, *}$, Mark A. Freeman ${ }^{2}$, Naoki Itoh ${ }^{3}$, Yutaka Fukuda ${ }^{4}$ \\ ${ }^{1}$ Department of Aquatic Bioscience, Graduate School of Agricultural and Life Sciences, The University of Tokyo, \\ Bunkyo, Tokyo 113-8657, Japan \\ ${ }^{2}$ Institute of Aquaculture, University of Stirling, Stirling FK9 4LA, UK \\ ${ }^{3}$ Department of Veterinary Science, Louisiana State University, Baton Rouge, Louisiana 70803, USA \\ ${ }^{4}$ Oita Institute of Marine and Fisheries Science, Kamiura, Oita 879-2602, Japan
}

\begin{abstract}
Skeletal deformities were found in the cultured Japanese mackerel Scomber japonicus. External and radiographical observations showed the deformed fish to exhibit a dorso-ventral spinal curvature (kyphosis) without fracture or dislocation of the vertebrae. Numerous myxosporean cysts, ca. 0.3 to $1.0 \mathrm{~mm}$ in diameter, formed in the 4 th ventricle, the cavity of the optic tectum, the surface of the olfactory lobe and bulb, the optic lobe and the inferior lobe of the brain. Spore morphology and molecular analysis of the small subunit ribosomal RNA gene sequence identified the myxosporean parasite as Myxobolus acanthogobii, a parasite which also causes scoliosis in yellowtail Seriola quinqeradiata. Histopathological observation showed that the myxosporean cysts were encapsulated within the host's collagenous layer although some had disintegrated to disperse mature spores into the cranial cavity. Occasionally, lymphocytic infiltration and local granulomatous inflammation were found to be associated with spore dispersion.
\end{abstract}

KEY WORDS: Myxozoa $\cdot$ Myxobolus $\cdot$ Spinal curvature $\cdot$ Parasite $\cdot$ Mackerel $\cdot$ Scomber japonicus

\section{INTRODUCTION}

The importance of the Japanese mackerel Scomber japonicus as a new mariculture fish species has recently increased in western parts of Japan, due to the high market value of the branded 'premium mackerel'. The quality of wild-caught mackerel deteriorates during the summer because of the spawning season. It is possible that, as a result of the success of the culture trials, a constant supply of good quality mackerel products may be achieved throughout the year. However, the occurrence of spinal curvatures in marketable-sized cultured mackerel has been observed recently, and is a potential cause of economic loss to the farmers.

Skeletal deformities of cultured yellowtail Seriola quinqueradiata have been well documented in Japan. Multiple factors are suspected to be associated with the disease, but a brain infection by a myxosporean has been indicated to be the primary cause of the skeletal abnormalities. This parasite was first designated as Myxobolus buri (Egusa 1985) and has been found from the brain of other wild fish such as Japanese bluefish Scombrops boops, red gurnard Chelidonichthys spinosus and brown-lined puffer Canthigaster rivulata (Maeno \& Sorimachi 1992). We were recently able to show from our morphological and molecular analyses that $M$. buri is synonymous with $M$. acanthogobii, which was previously described from the brain of the yellowfin goby Acanthogobius flavimanus (Hoshina 1952), and thus this parasite was reassigned as M. acanthogobii (Yokoyama et al. 2004). The present study aimed to identify by means of morphological and molecular analyses the causative myxosporean parasite in deformed mackerel. 


\section{MATERIALS AND METHODS}

Fish samplings and radiography. From December 2002 to May 2004, several deformed Japanese mackerel (0 to $1 \mathrm{yr}$ old) were supplied from fish farmers located in Oita prefecture, Japan. Following external observations, radiography of the diseased fish was performed with Fuji Lx film using a SOFTEX CMB-2 at 20 milliamps and $45 \mathrm{kV}$ for $90 \mathrm{~s}$. The skulls of the fish were opened using kitchen scissors, and the presence of myxosporean cysts in the brain was visually determined. Myxosporean cysts were excised to isolate spores, which were then preserved in a refrigerator $\left(4^{\circ} \mathrm{C}\right)$ or freezer $\left(-80^{\circ} \mathrm{C}\right)$ until required. To explore other etiological agents, bacteriological examinations were also performed.

To estimate the prevalence of infection, random samplings $(n=10)$ of cultured mackerel $(1 \mathrm{yr}$ old $)$ in the infected stock were conducted almost monthly from 26 March 2003 to 18 November 2003. The brain imprints were made, stained with Diff-Quik (International Reagents) and examined for myxosporean spores by light microscopy.

Morphological and histopathological examinations. Spores were embedded in $1.5 \%$ melted agar on a slide glass and observed by light microscopy. Digital images of spores were taken with an oil immersion objective and measurements were made based on 20 spores. $\mathrm{KOH}\left(0.2 \mathrm{~mol} \mathrm{l}^{-1}\right)$ was applied to spores to induce extrusion of the polar filaments, which were then measured. Descriptions and measurements were made in accordance with Lom \& Arthur (1989). The infected brain tissue was fixed in $10 \%$ buffered formalin and processed for routine histology. Five $\mu \mathrm{m}$ thick paraffin sections were cut, stained with hematoxylin and eosin (H \& E) and observed by light microscopy.

Molecular analysis. Myxosporean cysts were homogenised in $0.4 \mathrm{ml}$ high concentration urea buffer containing $100 \mathrm{\mu g} \mathrm{ml}^{-1}$ Proteinase $\mathrm{K}$ and digestion allowed to occur overnight at $56^{\circ} \mathrm{C}$. DNA was subsequently extracted using a QIAamp DNA Mini Kit (Qiagen) following the manufacturer's tissue protocol; the purified DNA was used as template DNA for subsequent PCR reactions. Small subunit ribosomal RNA (SSU rRNA) was amplified using the myxosporean primers described by Hallet \& Diamant (2001). After initial denaturation at $95^{\circ} \mathrm{C}$ for $4 \mathrm{~min}$, samples were subjected to 30 cycles of amplification (denaturation at $95^{\circ} \mathrm{C}$ for $30 \mathrm{~s}$, primer annealing at $55^{\circ} \mathrm{C}$ for $30 \mathrm{~s}$, and extension at $72^{\circ} \mathrm{C}$ for $30 \mathrm{~s}$ ), followed by a 7 min terminal extension at $72^{\circ} \mathrm{C}$. All amplifications were performed on a Bio-Rad I-cycler. The PCR products obtained were visualised in an ethidium bromidestained $1 \%$ agarose gel. PCR amplicons were purified using a PCR purification kit (Qiagen), and the resulting purified DNA was used as template DNA in direct sequencing reactions or cloned into a vector. PCR amplicons were cloned into a pt-7 Blue T-vector system (Takara). Recombinant plasmids and PCR products were sequenced with the dideoxy chain termination method (Sanger et al. 1977) using a BigDye ${ }^{\mathrm{TM}}$ Terminator Version 3.1 Cycle Sequencing Ready Reaction Kit and a 310 capillary DNA sequencer (Applied Biosystems), according to the manufacturer's instructions.

\section{RESULTS}

\section{Gross observation and radiography}

Diseased mackerel exhibited a dorso-ventral curvature or 'kyphosis' (Fig. 1A). The radiography clearly revealed a flexure of the ventral column like a smooth ' $\mathrm{S}$ ', which bent upwards in the 5 th to 7 th vertebrae and then curved downwards gradually in the posterior part of the body (Fig. 1B). No fractures or dislocations of vertebrae were evident. Although bacterial examinations were inconclusive, all deformed fish (11 out of 11) were found to be infected with a brain myxosporean.
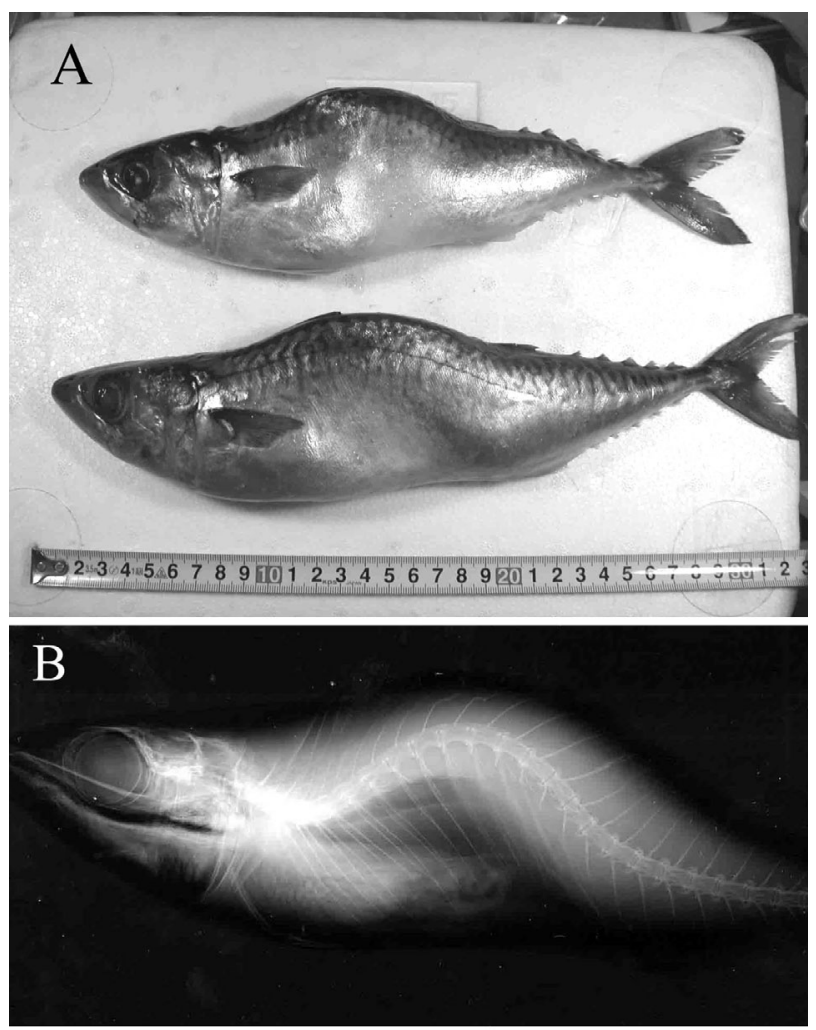

Fig. 1. Myxobolus acanthogobii infecting Scomber japonicus Deformed Japanese mackerel. (A) External appearance. Note the dorso-ventral S-like curvature. (B) Radiograph 
Masses of round, white cysts had formed on the surface of the olfactory lobe and bulb, the anterior end of the medulla oblongata and in the cavity of the brain tissue (Fig. 2).

During the period of disease outbreak, the prevalence of myxosporean infection in deformed and externally healthy fish from the same farm was 100 and $12.2 \%$, respectively. In periodic samplings, prevalence of infection increased between spring (March to June) and summer (July and August), reached a maximum of $40 \%$ in July, and then decreased in autumn (September to November) (Table 1).
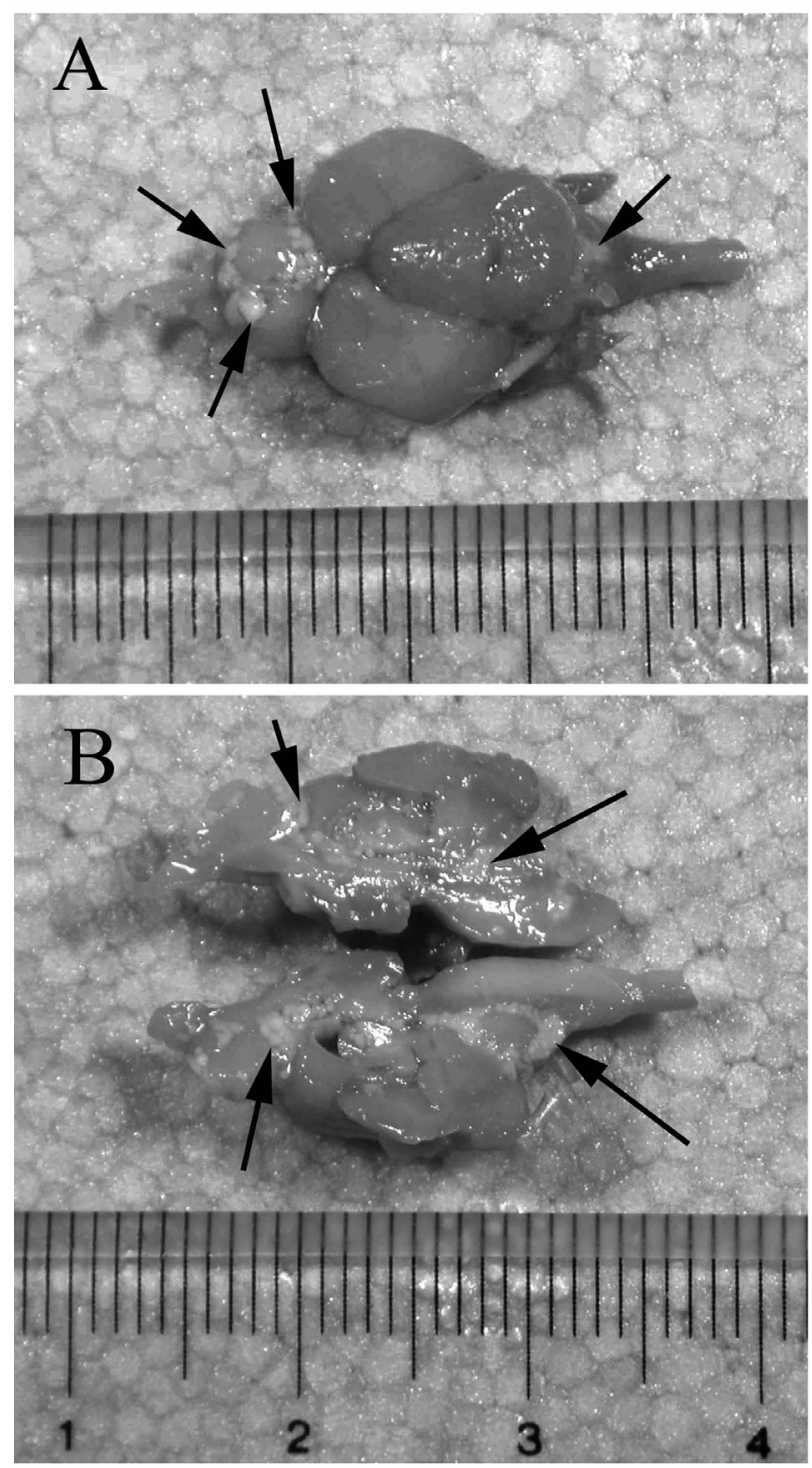

Fig. 2. Myxobolus acanthogobii infecting Scomber japonicus. The brain of deformed Japanese mackerel. (A) The excised whole brain. Arrows show several cysts located on the olfactory lobe and the anterior end of the medulla oblongata. (B) Divided brain tissue. Note masses of cysts (arrows) occupying the cavities of the brain tissue
Table 1. Myxobolus acanthogobii infecting Scomber japonicus. Prevalence of infection in the brain of cultured $1 \mathrm{yr}$ old Japanese mackerel $(n=10)$

\begin{tabular}{|lccc|}
\hline $\begin{array}{c}\text { Sampling } \\
\text { date } \\
(2003)\end{array}$ & $\begin{array}{c}\text { Average } \\
\text { fork } \\
\text { length (cm) }\end{array}$ & $\begin{array}{c}\text { Average } \\
\text { body } \\
\text { weight }(g)\end{array}$ & $\begin{array}{c}\text { Prevalence } \\
\text { of infection } \\
(\%)\end{array}$ \\
\hline 26 Mar & 26.4 & 279.1 & 0 \\
7 May & 28.0 & 352.5 & 10 \\
5 Jun & 28.0 & 335.0 & 0 \\
17 Jul & 27.7 & 257.9 & 40 \\
5 Aug & 29.4 & 325.0 & 20 \\
4 Sep & 29.2 & 319.6 & 10 \\
14 Oct & 29.5 & 366.7 & 20 \\
18 Nov & 29.7 & 380.6 & 0 \\
\hline
\end{tabular}

\section{Morphological and molecular analyses}

Spores were oval to ellipsoidal in frontal view, with a slightly attenuated posterior end (Fig. 3). The intercapsular process was prominent. Sutural ridges were conspicuous with several folds on the edge. The number of turns of the polar filament coil was 3. Two pyriform polar capsules were almost equal in size (Table 2). The data for Scomber japonicus are consistent with those of Myxobolus acanthogobii from yellowtail and yellowfin goby.

SSU rRNA gene sequences (18e/18g) of 1877 bases were obtained from the mackerel myxosporean, and showed $100 \%$ homology with that of Myxobolus acanthogobii from yellowtail and yellowfin goby (GenBank accession number: AY541585).

\section{Histopathological observation}

Numerous myxosporean cysts were observed to localize in the olfactory lobe, the optic lobe, the cavity of the optic tectum, the inferior lobe and the 4 th ventricle of the brain (Fig. 4). The cysts, ranging from ca. 0.3 to $1.0 \mathrm{~mm}$ in diameter, were encased by the host's collagenous layers and filled with maturing and mature spores (Fig. 5). Some were found to disintegrate, leading to dispersion of mature spores into the cranial cavity (Fig. 5A). Local degeneration of the neighboring nervous tissue, lymphocytic infiltration, and, occasionally, granulomatous inflammation were observed to be associated with the spore dispersion (Fig. 5C).

\section{DISCUSSION}

The morphological examinations in this study identified the myxosporean from deformed Japanese mackerel as Myxobolus acanthogobii, though minor varia- 

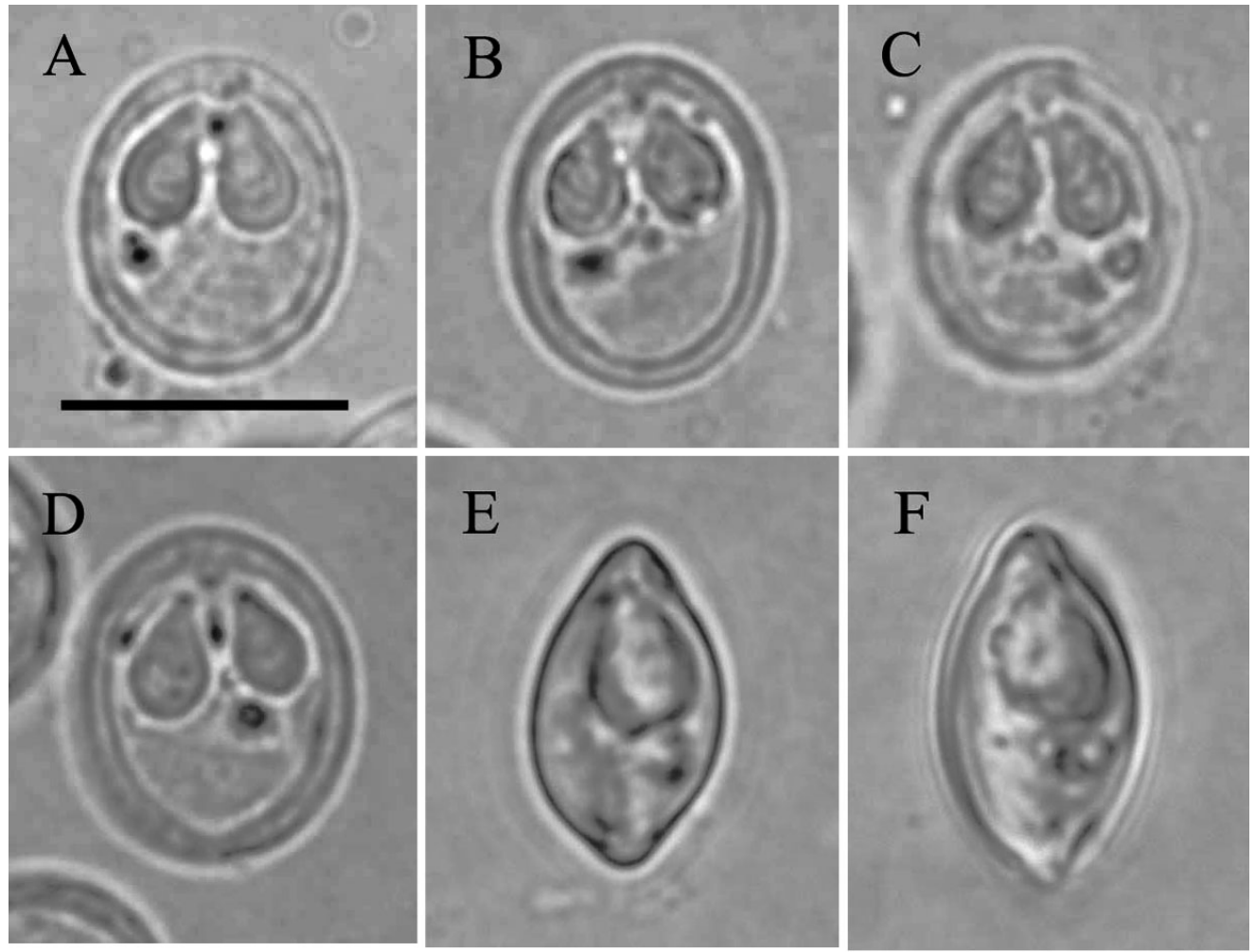

Fig. 3. Myxobolus acanthogobii infecting Scomber japonicus. Fresh spores from deformed Japanese mackerel. (A-D) Front views; $(\mathrm{E}, \mathrm{F})$ side views. Scale bar $=10 \mu \mathrm{m}$

Table 2. Myxobolus acanthogobii. Comparison of average spore dimensions $(\mu \mathrm{m})$ from various isolates. Range given within parentheses. nd: not determined due to formalin-fixed materials

\begin{tabular}{|c|c|c|c|c|c|c|c|}
\hline \multirow[t]{2}{*}{ Host } & \multicolumn{3}{|c|}{ Spore } & \multicolumn{2}{|c|}{ Polar capsule } & \multirow{2}{*}{$\begin{array}{l}\text { Polar filament } \\
\text { length }\end{array}$} & \multirow[t]{2}{*}{ Source } \\
\hline & Length & Width & Thickness & Length & Width & & \\
\hline $\begin{array}{l}\text { Seriola } \\
\quad \text { quinqueradiata }\end{array}$ & $\begin{array}{c}10.6 \\
(9.9-11.4)\end{array}$ & $\begin{array}{c}9.1 \\
(8.6-9.8)\end{array}$ & $\begin{array}{c}6.9 \\
(6.4-7.3)\end{array}$ & $\begin{array}{c}4.5 \\
(3.8-5.3)\end{array}$ & $\begin{array}{c}2.7 \\
(2.0-3.2)\end{array}$ & $\begin{array}{c}23.8 \\
(19.7-28.2)\end{array}$ & Yokoyama et al. (2004) \\
\hline $\begin{array}{l}\text { Seriola } \\
\text { quinqueradiata }\end{array}$ & $\begin{array}{c}10.6 \\
(9.2-11.8)\end{array}$ & $\begin{array}{c}9.2 \\
(7.9-10.2)\end{array}$ & $\begin{array}{c}6.6 \\
(5.5-7.3)\end{array}$ & $\begin{array}{c}4.5 \\
(3.9-5.4)\end{array}$ & $\begin{array}{c}2.8 \\
(2.5-3.4)\end{array}$ & $\begin{array}{c}30.6 \\
(17.1-40.3)\end{array}$ & Egusa (1985) \\
\hline $\begin{array}{l}\text { Acanthogobius } \\
\text { flavimanus }\end{array}$ & $\begin{array}{c}10.3 \\
(9.8-10.7)\end{array}$ & $\begin{array}{c}8.5 \\
(8.0-9.1)\end{array}$ & $\begin{array}{c}6.6 \\
(6.2-7.4)\end{array}$ & $\begin{array}{c}4.0 \\
(3.5-4.5)\end{array}$ & $\begin{array}{c}2.4 \\
(2.0-2.6)\end{array}$ & $\begin{array}{c}21.7 \\
(16.0-31.2)\end{array}$ & Yokoyama et al. (2004) \\
\hline $\begin{array}{l}\text { Acanthogobius } \\
\text { flavimanus }\end{array}$ & $\begin{array}{c}9.8 \\
(8.0-11.8)\end{array}$ & $\begin{array}{c}8.1 \\
(6.7-9.6)\end{array}$ & $\begin{array}{c}6.2 \\
(5.3-7.2)\end{array}$ & $\begin{array}{c}3.5 \\
(2.9-4.3)\end{array}$ & $\begin{array}{c}2.2 \\
(1.9-2.9)\end{array}$ & nd & Hoshina (1952) \\
\hline $\begin{array}{l}\text { Scomber } \\
\text { japonicus }\end{array}$ & $\begin{array}{c}10.2 \\
(9.5-11.0)\end{array}$ & $\begin{array}{c}8.4 \\
(7.8-9.3)\end{array}$ & $\begin{array}{c}5.9 \\
(4.9-6.6)\end{array}$ & $\begin{array}{c}4.0 \\
(3.4-4.4)\end{array}$ & $\begin{array}{c}2.4 \\
(2.2-2.7)\end{array}$ & $\begin{array}{c}17.0 \\
(11.7-24.4)\end{array}$ & This study \\
\hline
\end{tabular}

tions in spore dimensions were seen among the host species. It has been reported that the host difference could possibly affect the final size of mature spores (Diamant 1998). Since morphological characteristics have proven to be somewhat inadequate and ambiguous in myxozoan classification, molecular data have recently been utilised to support the validity of morphological evidence (Kent et al. 2001). SSU rRNA gene sequence analyses in the present study fully justified the specific identification of this myxosporean from Japanese mackerel.

Skeletal abnormalities of fish have been associated with various factors, e.g. pesticide exposure (Couch et al. 1977, Middaugh et al. 1990) and nutritional defi- 


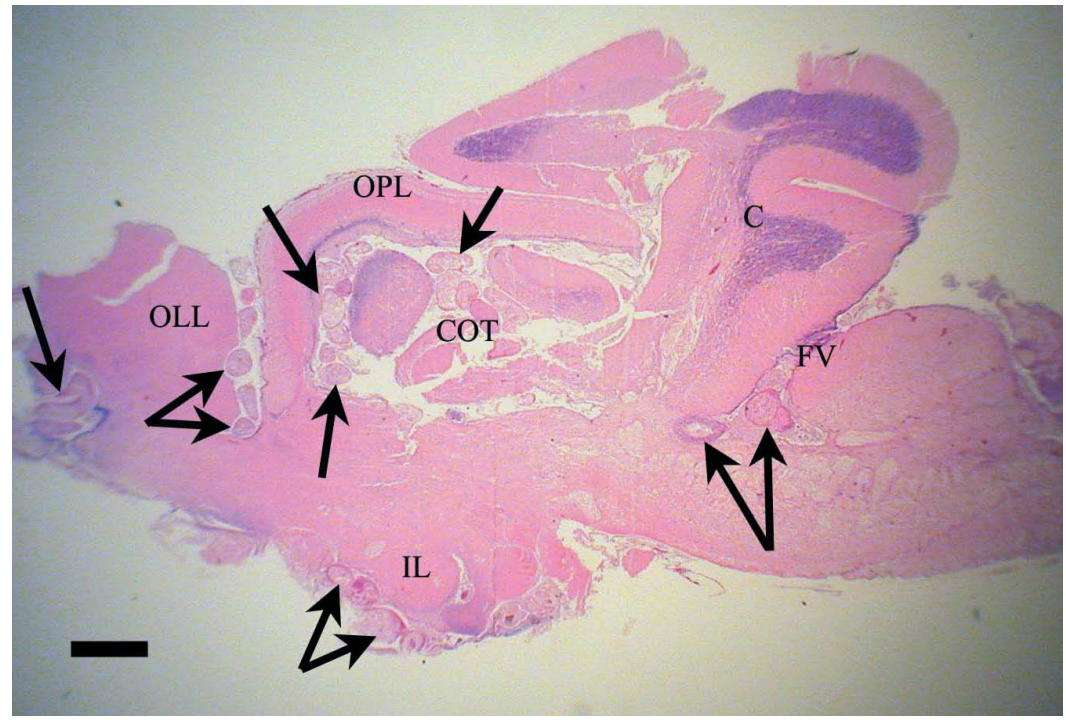

Fig. 4. Myxobolus acanthogobii infecting Scomber japonicus. Longitudinal section of the brain. Arrows show the cysts of M. acanthogobii. OLL: olfactory lobe; OPL: optic lobe; COT: the cavity of optic tectum; C: cerebellum; FV: 4th ventricle; IL: inferior lobe. Hematoxylin and eosin (H\&E) stain. Scale bar $=1 \mathrm{~mm}$ affects the central nervous system of yellowtail, inducing motor disturbances which finally lead to spinal curvature. In the present study, myxosporean cysts were also found in various regions of the brain of deformed mackerel, but the anatomical location of cysts responsible for the skeletal anomalies could not be determined. The causal relation between cyst distribution and spinal deformity remains to be studied

It should also be noted that the diseased Japanese mackerel exhibited a dorso-ventral bend (kyphosis) which is considered to be pathognomonic for the disease. It is well documented that yellowtail infected with Myxobolus acanthogobii display an S-curvature in the lateral plane (scoliosis). Maeno \& Sorimachi (1992) reported that Japanese bluefish with $M$. buri (= M. acanthogobii) showed a dorso-ventral deformity, but the curvature appeared irregular ciencies (Akiyama et al. 1986) as well as infectious agents including viruses (LaPatra et al. 2001), bacteria (Kaige et al. 1984), and a wide variety of parasites such as microsporidians (Matthews et al. 2001), digenean metacercaria (Kent et al. 2004) and myxozoans (Bucke \& Andrews 1985, Langdon 1987, Treasurer 1992, Hedrick et al. 1998, Longshaw et al. 2003). Most myxozoans causing vertebral anomalies in fishes infect the brain tissues or spinal column, but some infect the somatic muscle adjacent to the vertebrae (Kent et al. 2004). In any case, it is likely that the presence of parasitic masses or granulomatous lesions interferes with the nervous system, leading to myopathy of the axial muscles and asymmetrical changes in muscle tone (Lom et al. 1991). The evidence shown in the present study strongly suggests that Myxobolus acanthogobii is the cause of vertebral deformity of Japanese mackerel. It is also notable that $12.2 \%$ of externally healthy fish in the infected stock were infected with $M$. acanthogobii. It is possible that onset of the disease depends on the intensity of infection or location of cysts in the brain.

Sakaguchi et al. (1987) and Maeno \& Sorimachi (1992) found myxosporean cysts in various locations of the brain of deformed yellowtail, such as the 4th ventricle, the cavity of the optic tectum, and the surface of the olfactory lobe and bulb. Further, they reported that cysts were always observed in the 4th ventricle and less frequently in the other regions, though no cysts were detected in the 4 th ventricle of externally normal but infected fish. Overall, results indicated that myxosporean infection in the 4 th ventricle mechanically (not like a smooth 'S'). Although redfin perch Perca fluviatilis infected with Triangula percae likewise exhibited curvature in the dorso-ventral plane, the flexure could consist of several (not a single) smooth ' $\mathrm{S}$ ' bends (Langdon 1987). Interestingly, the type of curvature in deformed mullet Mugil cephalus due to Myxobolus spinacurvatura infection is a lordo-scoliosis (Maeno \& Sorimachi 1992). In contrast, $M$. acanthogobii does not cause any skeletal abnormalities in the yellowfin goby or brown-lined puffer. Further studies are required to clarify the varying pathological effects observed in different host fishes.

Based on a preliminary investigation in the present study, the prevalence of infection with Myxobolus acanthogobii in cultured mackerel appeared to be 10 to $40 \%$ in the farm studied. It is likely that the decrease of the prevalence in autumn may result from the disintegration of myxosporean cysts in the brain. The actual prevalence, morbidity rate and distribution of the parasite in the coastal areas of Japan where the hosts (mackerel, yellowtail and gobies) live are as yet unknown. An epizootiological survey using a molecular diagnostic tool (Yokoyama et al. 2004) is now underway.

In conclusion, the morphological and molecular analyses demonstrated that spinal curvature of Japanese mackerel was caused by a brain myxosporean Myxobolus acanthogobii, which has been reported to infect the brain of yellowtail and yellowfin goby in previous studies. It was evident that there are significant differences in pathological effects among the host species. 

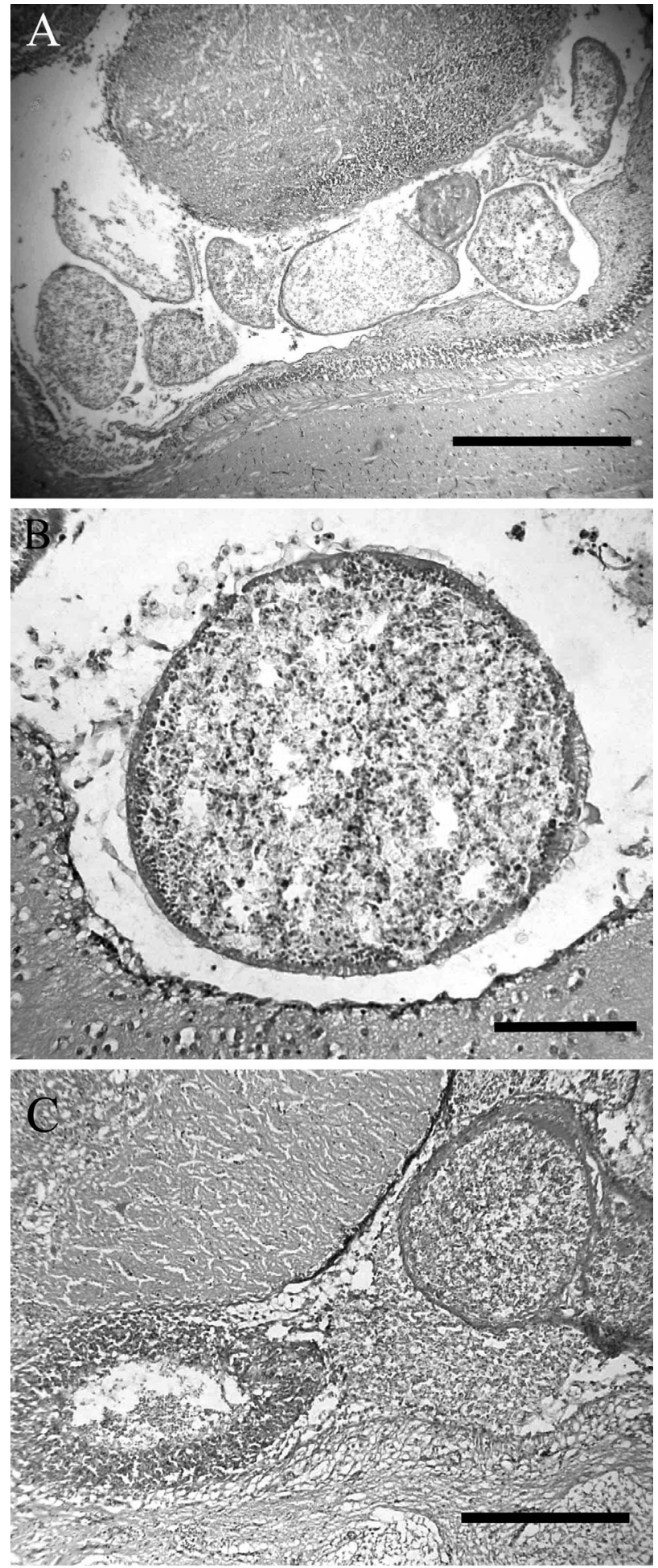

Fig. 5. Myxobolus acanthogobii infecting Scomber japonicus. Histopathology of the brain. (A) Several cysts located in the cavity of the optic tectum. Note that some cysts disintegrate to release the spores. Scale bar $=500 \mu \mathrm{m}$. (B) High magnification of a myxosporean cyst. Scale bar $=100 \mu \mathrm{m}$. (C) Local lymphocytic infiltration associated with spore dispersion in the 4th ventricle. $H \& E$ stain. Scale bar $=300 \mu \mathrm{m}$
Acknowledgements. We thank S. Hayashi and S. Miyajima of the University of Tokyo for their technical assistance.

\section{LITERATURE CITED}

Akiyama T, Murai T, Nose T (1986) Oral administration of serotonin against spinal deformity of chum salmon fry induced by tryptophan deficiency. Bull Jpn Soc Sci Fish 5: 1249-1254

Bucke D, Andrews C (1985) Vertebral anomalies in chub Leuciscus (Squalius) cephalus L. Bull Eur Assoc Fish Pathol 5: $3-5$

Couch JA, Winstead JT, Goodman LR (1977) Kepone-induced scoliosis and its histological consequences in fish. Science 197:585-587

Diamant A (1998) Red drum Sciaenops ocellatus (Sciaenidae), a recent introduction to Mediterranean mariculture, is susceptible to Myxidium leei (Myxosporea). Aquaculture 162: $33-39$

Egusa S (1985) Myxobolus buri sp. n. (Myxosporea: Bivalvulida) parasitic in the brain of Seriola quinqueradiata Temminck et Schlegel. Fish Pathol 19:239-244

Hallet SL, Diamant A (2001) Ultrastructure and small-subunit ribosomal DNA sequence of Henneguya lesteri n. sp. (Myxosporea), a parasite of sand whiting Sillago analis (Sillaginidae) from the coast of Queensland, Australia. Dis Aquat Org 46:197-212

Hedrick RP, El-Matbouli M, Adkison MA, MacConnell E (1998) Whirling disease: reemergence among wild trout. Immunol Rev 166:365-376

Hoshina T (1952) Notes on some myxosporidian parasites on fishes of Japan. J Tokyo Univ Fish 39:69-89

Kaige N, Miyazaki T, Kubota S (1984) The pathogen and the histopathology of vertebral deformity in cultured yellowtail. Fish Pathol 19:173-179

Kent ML, Andree KB, Bartholomew JL, El-Matbouli M and 12 others (2001) Recent advances in our knowledge of the Myxozoa. J Eukaryot Microbiol 48:395-413

Kent ML, Watral VG, Whipps CM, Cunningham ME and 5 others (2004) A digenean metacercaria (Apophallus sp.) and a myxozoan (Myxobolus sp.) associated with vertebral deformities in cyprinid fishes from the Willamette River, Oregon. J Aquat Anim Health 6:116-129

Langdon JS (1987) Spinal curvatures and an encephalotropic myxosporean, Triangula percae sp. nov. (Myxozoa: Ortholineidae), enzootic in redfin perch, Perca fluviatilis L., in Australia. J Fish Dis 10:425-434

LaPatra SE, Batts WN, Overturf K, Jones GR, Shewmaker WD, Winton JR (2001) Negligible risk associated with the movement of processed rainbow trout, Oncorhynchus mykiss (Walboum), from an infectious haematopoietic necrosis virus (IHNV) endemic area. J Fish Dis 24: 399-408

Lom J, Arthur JR (1989) A guideline for the preparation of species descriptions in Myxosporea. J Fish Dis 12:151-156

Lom J, Pike AW, Dykova I (1991) Myxobolus sandrae Reuss, 1906, the agent of vertebral column deformities of perch Perca fluviatilis in northeast Scotland. Dis Aquat Org 12: $49-53$

Longshaw M, Frear P, Feist SW (2003) Myxobolus buckei sp. n. (Myxozoa), a new pathogenic parasite from the spinal column of three cyprinid fishes from the United Kingdom. Folia Parasitol 50:251-262

Maeno Y, Sorimachi M (1992) Skeletal abnormalities of fishes caused by parasitism of Myxosporea. NOAA Tech Rep NMFS 111:113-118 
Matthews JL, Brown AMV, Larison K, Bishop-Stewart JK, Rogers P, Kent ML (2001) Pseudoloma neurophilia n. g., n. sp., a new genus and species of Microsporidia from the central nervous system of the zebrafish (Danio renio). J Eukaryot Microbiol 48:229-235

Middaugh DP, Fournie JW, Hemmer MJ (1990) Vertebral abnormalities in juvenile inland silversides Menidia beryllina exposed to terbufos during embryogenesis. Dis Aquat Org 9:109-116

Sakaguchi S, Hara T, Matsusato T, Shibahara T, Yamagata Y, Kawai H, Maeno Y (1987) Scoliosis of cultured yellowtail caused by parasitic Myxobolus buri. Bull Natl Res Inst

Editorial responsibility: Wolfgang Körting,

Hannover, Germany
Aquacult 12:79-86

Sanger F, Nicklen S, Coulson AR (1977) DNA sequencing with chain terminating inhibitors. Proc Natl Acad Sci 74: 5463-547

Treasurer J (1992) Vertebral anomalies associated with Myxobolus sp. in perch, Perca fluviatilis L., in a Scottish Loch. Bull Eur Assoc Fish Pathol 12:61-63

Yokoyama H, Freeman MA, Yoshinaga T, Ogawa K (2004) Myxobolus buri, the myxosporean parasite causing scoliosis of yellowtail, is synonymous with Myxobolus acanthogobii infecting the brain of the yellowfin goby. Fish Sci 70:1036-1042

Submitted: September 21, 2004; Accepted: February 11, 2005 Proofs received from author(s): July 7, 2005 